\title{
Characteristics of sprite and gravity wave convective sources present in satellite IR images during the SpreadFEx 2005 in Brazil
}

\author{
F. T. São Sabbas ${ }^{1}$, V. T. Rampinelli ${ }^{1}$, J. Santiago ${ }^{1}$, P. Stamus ${ }^{2}$, S. L. Vadas $^{2}$, D. C. Fritts ${ }^{2}$, M. J. Taylor ${ }^{3}$, P. D. Pautet ${ }^{3}$, \\ G. Dolif Neto ${ }^{4}$, and O. Pinto ${ }^{1}$ \\ ${ }^{1}$ National Institute for Space Research - INPE, São José dos Campos, São Paulo, Brazil \\ ${ }^{2}$ Northwest Research Associates, CoRA Division, Boulder, CO, USA \\ ${ }^{3}$ Utah State University, Logan, Utah, USA \\ ${ }^{4}$ Center of Weather Forecast and Climate Studies/INPE, Cachoeira Paulista, São Paulo, Brazil
}

Received: 6 May 2008 - Revised: 5 January 2009 - Accepted: 13 January 2009 - Published: 13 March 2009

\begin{abstract}
We developed a technique to identify and estimate the size, intensity, and Tropopause overshoot of thunderstorm convective cores expected to be significant sources of gravity waves. The work was based on GOES IR images of South America on the night of 30 September to 1 October and 25-26 October 2005, as part of the Spread F Experiment (SpreadFEx) in Brazil in 2005. We also characterized, for the first time, the convective activity of three small TLE producing thunderstorms that yielded 11 TLEs on 2526 October 2005. The campaign occurred during the dry to wet season transition in central Brazil, marked by the presence of extra-tropical cyclogenesis over the Atlantic Ocean, and cold fronts penetrating inland. The Tropopause temperature was typically $-76^{\circ} \mathrm{C}$ with a corresponding altitude of $\sim 15200 \mathrm{~m}$. Vigorous convective cores capable of generating strong gravity waves were located in convective regions having areas with cloud top temperatures $\leq-76^{\circ} \mathrm{C}$. They had typical cloud-top temperature deficits of $\Delta T-2.0^{\circ} \mathrm{C}$ to $-8.0^{\circ} \mathrm{C}$ from the average surroundings, implying overshoot heights of 200 to $3100 \mathrm{~m}$, which are within the typical range. Fast vertical development and high horizontal growth rates were associated with a large number of simultaneously active vigorous convective cores, indicating that their dynamics may have determined the spatial-temporal development of the thunderstorms analyzed. Moderate convective cores were also present in areas with cloud top $-76^{\circ} \mathrm{C} \leq T \leq-70^{\circ} \mathrm{C}$. They had $\Delta T$ of $-1.9^{\circ} \mathrm{C}$ to $-5.3^{\circ} \mathrm{C}$ producing overshoots between $80-300 \mathrm{~m}$. All convective cores had typical diameters of $5-20 \mathrm{~km}$ and their size tended to increase with $\Delta T$, there was a $57 \%$ correlation between the two parameters.
\end{abstract}

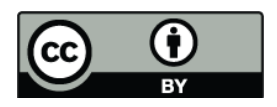

Correspondence to: F. T. São Sabbas (saosabbas@dae.inpe.br)
Analysis of the relationship of cloud top $T$ with positive and negative cloud-to-ground lightning $(+/-\mathrm{CG})$ occurrence rate and with peak current showed that lighting activity may provide an independent way to identify convective cores and measure their intensity, since they were characterized by a high incidence of low peak current -CGs that forms the bulk of the $-\mathrm{CG}$ population.

Keywords. Atmospheric composition and structure (Airglow and aurora) - Meteorology and atmospheric dynamics (Atmospheric electricity; Convective processes)

\section{Introduction}

Between September and November 2005, the Spread F Experiment (SpreadFEx) was performed in Brazil with the main goal of investigating the potential role of gravity waves (GWs) in seeding ionospheric irregularities. The premise being tested was whether GWs generated by deep tropical convection could penetrate from the troposphere to the bottomside $\mathrm{F}$ layer and cause sufficient perturbations of the winds and plasma densities to impact the growth rates of instabilities triggering plasma bubbles extending to much higher altitudes. To address these questions, SpreadFEx measurements were designed to provide sensitivity to GWs arising from strong convective sources, to their propagation, and observed characteristics in the mesosphere and lower thermosphere (MLT). The measurements were also planed to address their attainment of the bottomside F layer and their apparent scales and amplitudes at this region.

A secondary objective of the SpreadFEx campaign was related to the potential impact of GW neutral density perturbations at mesospheric altitudes on sprite initiation processes.

Published by Copernicus Publications on behalf of the European Geosciences Union. 
Sprites are one of several optical observable components of electrical energy deposition in the middle/upper atmosphere by lightning, generally dubbed Transient Luminous Events (TLEs). They are excited by the transient quasi-electrostatic electric fields established in the mesosphere (Pasko et al., 1997b) after some cloud-to-ground discharges, generally of positive polarity $(+\mathrm{CGs})$, occur. GW density modulations may lower the electric breakdown threshold that trigger sprites at multiple locations offset from the causative lighting discharge (Pasko et al., 1997a; São Sabbas, 2003), in agreement with observations (Wescott et al., 1998, 2001; São Sabbas et al., 2003a).

In order to perform experimental investigations of both objectives, a large set of instruments, including airglow and sprite imagers, ionosondes, radars, and GPS receivers concentrated in strategic sites from the magnetic equator to $11^{\circ} \mathrm{S}$ magnetic longitude, and at an INPE facility at $\sim 17^{\circ} \mathrm{S}$, were operated during the campaign. The observational components of SpreadFEx were augmented with modeling and theoretical efforts intended to further quantify potential GW penetration to high altitudes and their ionospheric effects. A more complete discussion of the motivations for SpreadFEx, the two campaign measurement sequences, and a summary of SpreadFEx results is provided in the overview by Fritts et al. (2009a, b).

Deep convection is now known to be a significant source of GWs expected to penetrate to high altitudes, and is also the main mechanism of thunderstorm electrification. $\mathrm{Nu}-$ merical studies indicate that convection excites GWs on a wide range of spatial and temporal scales (Piani et al., 2000; Lane et al., 2001), while airglow measurements have provided clear evidence of circular GW perturbations arising from deep convection in the MLT in close proximity to the convective sources (Taylor and Hapgood, 1988; Sentman et al., 2003). Sprites and other upper atmospheric TLEs have also been observed together with GWs demonstrating that electrically active thunderstorms can be sources of both phenomena (Sentman et al., 2003).

On several nights during the campaign the zenith sky was predominately clear and GWs and ionospheric plasma bubbles were recorded by the airglow equipment at the optical site located at São João do Cariri - SJC $\left(7.4^{\circ} \mathrm{S}, 36.5^{\circ} \mathrm{W}\right)$, in Paraíba State at the Northeast Region, and São João d'Aliança - SJA $\left(-14.7^{\circ} \mathrm{S},-47.5^{\circ} \mathrm{W}\right)$, in Goiás over central Brazil. Taylor et al. (2009) identified GW structures in the MLT airglow measurements from SJA during the SpreadFEx campaign that were reverse ray traced by Vadas et al. (2009) and Wrasse et al. (2009). The extensive data set collected by the ionospheric diagnostic instruments spread over Brazil recorded the presence of plasma bubbles on coincident nights permitting several studies assessing the GW and tidal impacts on plasma instability processes at the bottomside F layer (Abdu et al., 2009; Kherani et al., 2009; Takahashi et al., 2009) by the large wavelength and high intrinsic frequency GWs expected to penetrate well into the thermosphere (Vadas and Fritts, 2004, 2006; Fritts and Vadas, 2008; Vargas et al., 2009).

Sprite observations require a special combination of atmospheric conditions, including electrically active thunderstorms in the clear sky horizon, which were satisfied on a single night, 25-26 October 2005. A total of 11 events were detected from São João d'Aliança, where the sprite imagers were located. However, on this night the zenith was predominantly cloudy which limited GWs detection, so further observations will be required to address the possible GW seeding of sprites.

In this paper we describe the general meteorological scenario and convective activity during the SpreadFEx campaign. We report the sprite observations obtained on the night of 25-26 October 2005, and characterize the spatial and temporal development of strong convective regions present in GOES IR satellite images of South America on this night and on the night of 30 September to 1 October, one of the 4 nights when Taylor et al. (2009) observed 6 medium-scale GWs, with horizontal wavelengths of $\lambda_{H}=60-160 \mathrm{~km}$, over central Brazil.

In order to further gauge the level of convection inside those regions we analyzed their electrical activity using CG lightning data from the BrasilDAT network. We developed a technique to identify the convective cores within thunderstorms convective regions capable of exciting GWs. We also determined convective core locations, i.e. latitude and longitude, and estimated their spatial scales and intensities based on the satellite imagery. Results from this study provide realistic parameterization of GW characteristic spatial and temporal scales arising from individual deep convective sources.

\section{Meteorological scenario and general convective pat- tern during the campaign}

The SpreadFEx had two periods of observations during "moon down" phase starting on 25 September and ending on 8 November 2005. The central region of Brazil, where most of the deep convection capable of exciting gravity wave was located, was undergoing a typical transition between a dry and wet season during the campaign. This transition is marked by alternating dry and extremely hot periods with periods of strong convective rain. The spring season in the Southern Hemisphere started on 22 September at 19:23 UTC. Convection and rain fall registered for Mato Grosso and Mato Grosso do Sul States were above the average during September. In October the northern-central portion of Brazil rainfall was scanty and the monthly totals of precipitation were below the climatological values. The convective activity was mainly due to Large Scale Atmospheric Rossby Waves that produced extra tropical cyclone genesis over the Atlantic Ocean, and cold fronts that propagated over the Brazilian territory. 

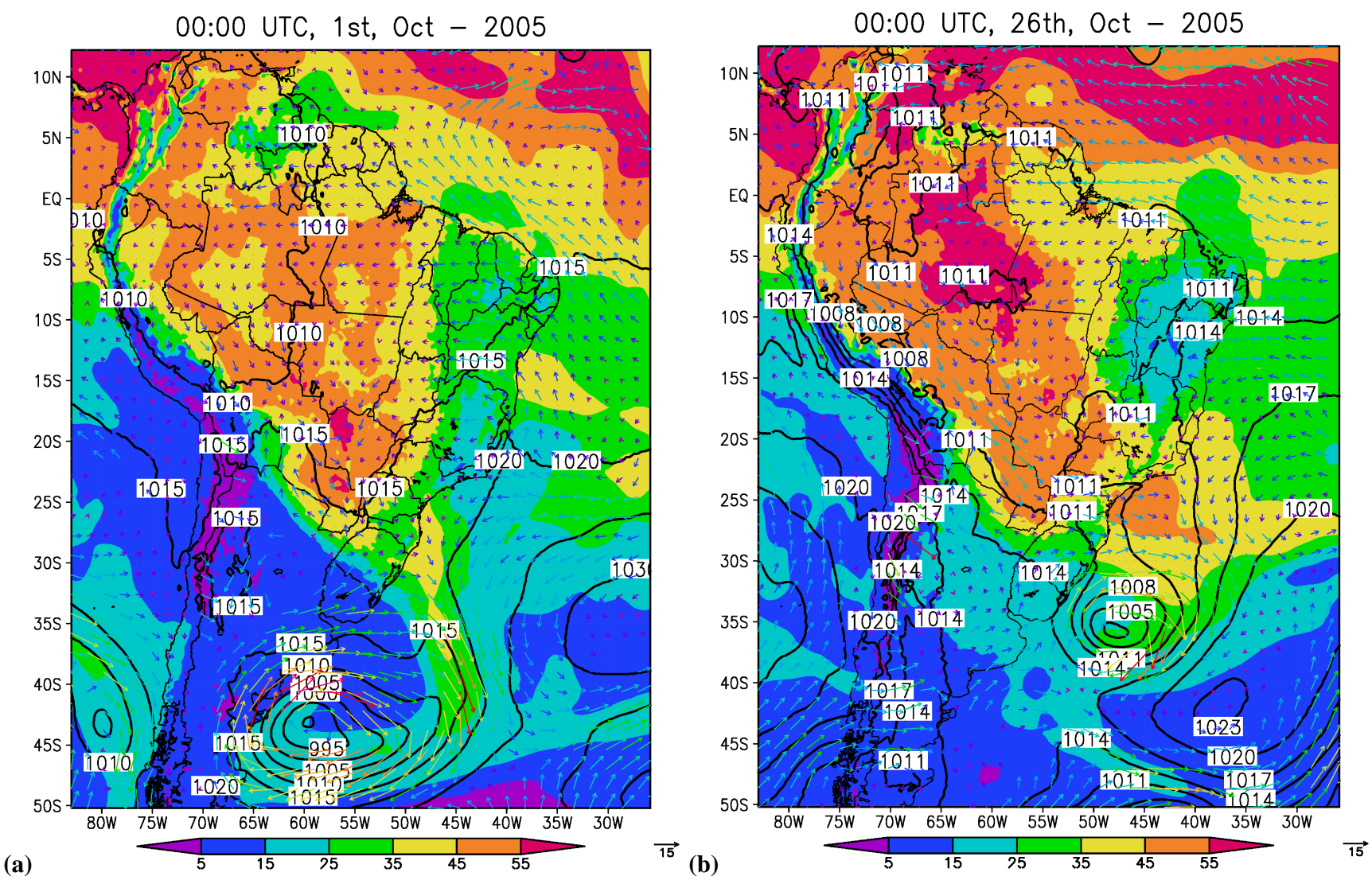

Fig. 1. Sea level pressure (hPa - contour), precipitable water ( $\mathrm{mm}$ - colored), $850 \mathrm{hPa}$ wind (m/s - vector) for 00:00 Z, 1 October 2005, on the left (a), and 00:00 Z, 26 October 2005, on the right (b).

On the night of 30 September to 1 October 2005, convection was dominated by wide spread late afternoon small thunderstorms, that dissipated before local midnight, with the presence of a few longer lived Mesoscale Convective Systems (MCS). On the night when sprites were observed, 25 to 26 October 2005, convection was also wide spread however it was disorganized and started to intensify around noon. The small short lived convective cells initiated and decayed continuously without forming MCS, and advected anvil material got mixed up forming extense cloud covers. This type of convection was a consequence of the association of high pressure on higher tropical levels $(250 \mathrm{hPa})$, which favors wind divergence on high levels, and an extra-tropical cyclone over the Atlantic ocean, which creates a moisture transport southwards from the Amazon Basin towards Southern Brazil. The warm moist air from the Amazon is forced upwards by the cyclonic circulation giving rise to deep convection over central Brazil.

On the night of 30 September to 1 October 2005, convection was somewhat more localized than on the sprite night (25-26 October 2005). Nevertheless the synoptic scenario was very similar to $25-26$ October 2005 , there was also an extra-tropical cyclone over the Atlantic and a low level jet pattern over central South America advecting moisture for deep convection, typical of this dry to wet transition season. The significant difference between these nights was the location of the cyclone center. On 1 October 2005, it was positioned at higher latitudes transporting moisture down to those latitudes, as shown in Fig. 1a, and on 26 October 2005, the cyclone was located at the Southeastern Brazilian coast, making greater amounts of precipitable water available in Northern and Central Brazil (Fig. 1b).

\section{Data set}

To study the convective activity on the two SpreadFEx selected nights we examined South America images of the GOES 12 satellite $10-12 \mu \mathrm{m}$ IR channel. The data were provided by the Brazilian Center of Weather Forecast and Climate Studies, CPTEC/INPE. GOES 12 scans South America every $30 \mathrm{~min}$, producing an image file covering approximately $27.5^{\circ}$ to $-47.8^{\circ}$ latitude and $-26.7^{\circ}$ to $-106.1^{\circ}$ longitude, and two other files holding the latitude and longitude of each pixel in the image. CPTEC provided pre-processed temperature data, i.e. the count values were 


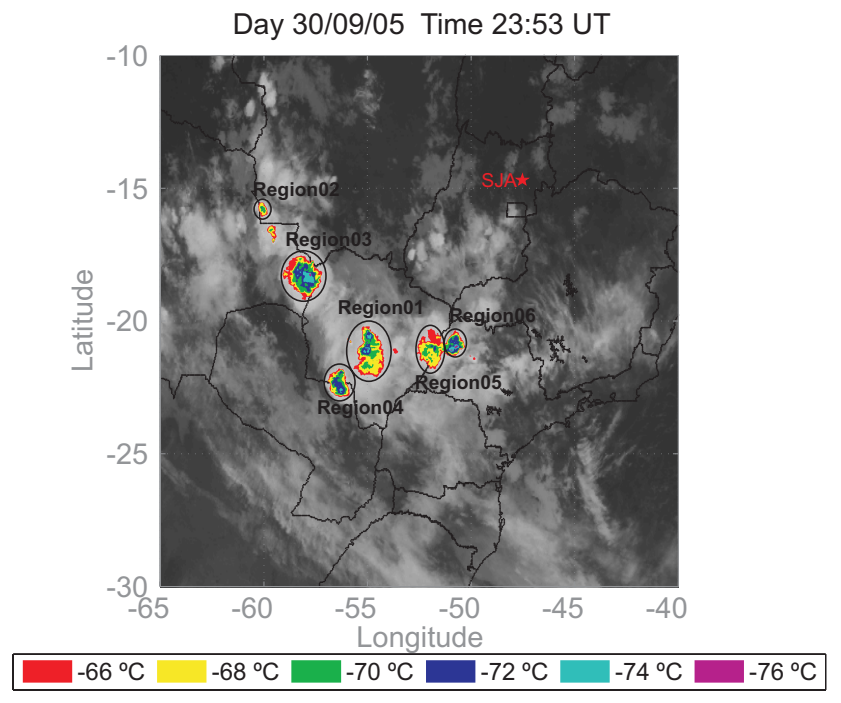

Fig. 2. Grayscale GOES 12 IR image of Brazil's Central-West, part of Southeast regions and neighboring countries (Bolivia, Paraguay and Argentina) of the night of 30 September-1 October 2005. It shows the locations of the cloud top regions with $T<-66^{\circ} \mathrm{C}$ color enhanced in $2^{\circ} \mathrm{C}$ intervals. The 6 selected convective regions are indicated with circles.

already converted into temperature by automated satellite ground station software. The temperatures are accurate to $0.4 \mathrm{~K}$ and the spatial resolution of the images is approximately $4 \mathrm{~km}$ at the equator. The part of the image corresponding to the central region of Brazil was isolated and remapped from satellite projection to an isometric latitude and longitude grid.

We also analyzed the lighting activity of the convective regions relative to the cloud top temperature in order to better understand the convection intensity at different parts of the thunderstorms. The lightning data were collected by the Brazilian Lightning Detection Network - BrasilDAT (Pinto et al., 2007), a network similar to the American National Lightning Detection Network - NLDN (Cummins et al., 1998). BrasilDAT provides the latitude, longitude, peak current and polarity of cloud-to-ground lightning discharges. In order to minimize the error due to the thunderstorm displacement and feature development we considered lightning that had occurred up to $15 \mathrm{~min}$ before or after the image (São Sabbas et al., 2003b, 2007).

On the night of 25-26 October 2005, TLEs were observed using two Gen III intensified Xybion ISG780 cameras from Utah State University. The cameras were installed at the SJA optical observation site about $250 \mathrm{~km}$ north of Brasília. The cameras were fitted with lenses that provided a horizontal field of view (FOV) of $\sim 20^{\circ}$ and were positioned side by side in order to have overlapping fov. The data were recorded in digital video tapes and the sprite locations were estimated by an image analysis method that uses the star field appear-

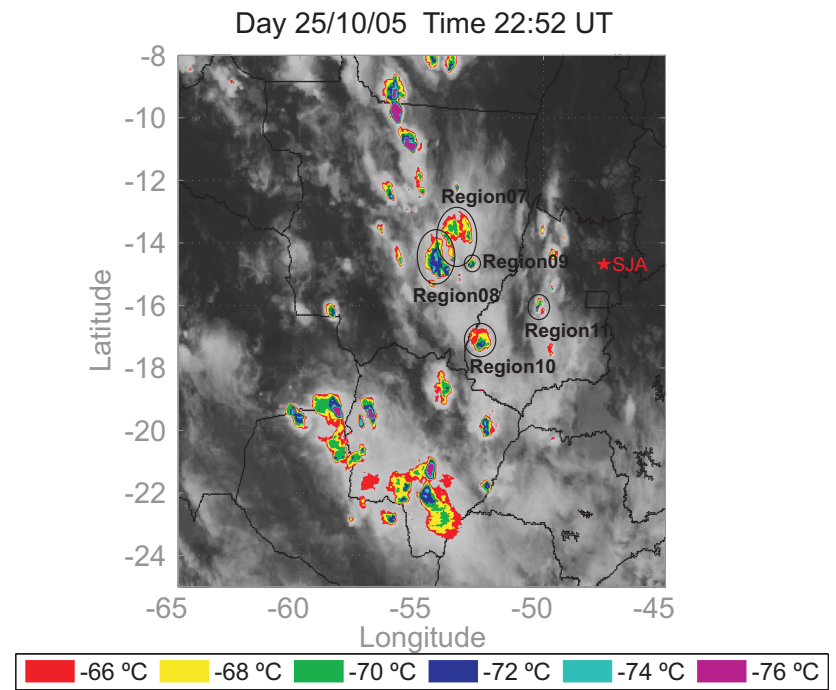

Fig. 3. Grayscale GOES 12 IR image showing the locations of the 5 convective regions of the TLE producing thunderstorms of the night of 25-26 October 2005. The location of the observation site, SJA, is also shown for reference.

ing on the digitized images. The latitude and longitude of the sprites were estimated assuming that their tops were at $80 \mathrm{~km}$ altitude. The accuracy of this method depends on the distance between the site and the TLE, and the error in the altitude assumption, e.g. a $5 \mathrm{~km}$ error on the altitude assumption translates into an error of $\sim 5 \%$ on the measured range.

\section{Characterization of convective regions and identifica- tion of convective cores}

Strong convective regions were identified based on the IR cloud top temperatures obtained from GOES 12 IR satellite images. To focus on the most vigorous convection we only selected areas with temperatures $\leq-66^{\circ} \mathrm{C}$. The analysis of the structures and dynamics of these areas was performed by color coding the pixels with $T \leq-66^{\circ} \mathrm{C}$ to $-76^{\circ} \mathrm{C}$ in $2^{\circ} \mathrm{C}$ intervals, and leaving the warmer areas in grayscale, as shown in Fig. 2, for 30 September 2005, and in Fig. 3, for 25 October 2005 .

The coldest spots and the immediately adjacent areas show regions where there were strong convective cores, since when energetic convective cores overshoot the Tropopause, the air is much colder than the surrounding air. Oscillating updrafts and down drafts impacting the Tropopause are the main convective forcing in the "mechanic oscillator" mechanism to generate gravity waves demonstrated by Fovell et al. (1989). Because the excited gravity wave amplitudes are proportional to the convective core updraft velocity, stronger updrafts lead to larger-amplitude gravity waves. Thus, those coldest areas denote those convective cores with the potential to generate gravity waves which can propagate to the 
thermosphere. The Tropopause temperature was estimated at $-76^{\circ} \mathrm{C}$, corresponding to an altitude of $\sim 15200 \mathrm{~m}$, based on atmospheric temperature profiles of 30 September and 1 October 2005, from balloon soundings at Brasília (15.86 S, 47.93 W), shown in Fig. 4.

For computational purposes, we defined the general area of the convective regions as being the regions with $T \leq-66^{\circ} \mathrm{C}$. We calculated the area of each Region, the lightning rate, and average peak current associated with their cloud top temperatures. Throughout the lifetimes of some Regions, there were times when they were attached to other regions forming small convective complexes. When this was the case, we imposed artificial boundaries at the locations they connected, in order to calculate the area of the specific Region of interest.

In order to identify the convective cores of a given convective region, we calculated the average temperature $\left(T_{a v}\right)$ of the coldest cloud tops and their surroundings. The strongest convective cores were located at areas with cloud tops $T \leq-76^{\circ} \mathrm{C}$, so when these areas were present we used $T \leq-74^{\circ} \mathrm{C}$ as a threshold and the convective cores were classified as vigorous, otherwise the threshold was $T \leq-70^{\circ} \mathrm{C}$ and the convective cores were considered to be moderate. To calculate the $T_{a v}$ we added the temperature of all pixels whose values were lower than the threshold and divided by the total number of pixels. Then we calculated the difference between the temperature of the pixel and the average, $\Delta T=T_{\text {pixel }}-T_{a v}$. The pixels with the lowest $\Delta T$ were selected as the "center" of the convective cores $\left(T_{\text {core }}\right)$ and their area was estimated by adding the area of surrounding pixels until $\Delta T=T_{\text {core }} / 2$.

In most cases the temperature gradient around the convective core center was rather sharp, the number of pixels with $\Delta T \leq T_{\text {core }} / 2$ was small, and all of them were included. For the few convective cores that extended to larger areas and/or merged with other convective cores, only a few pixels outward in each direction from the coldest spot were included. To get the convective core approximate diameters from the estimated areas we assumed that the convective cores had a circular shape. We also estimated the Tropopause overshoot of the convective cores by subtracting the altitude of the convective core, obtained making a simple comparison between $T_{\text {core }}$ and the balloon soundings (Fig. 4), from the Tropopause altitude (Adler and Fenn, 1979; Heymsfield and Blackmer, 1988). The $\Delta T$ and resulting overshoot are important parameters to gauge the convective core convective intensity since they are a direct consequence of the updraft velocity inside them. Overshoot areas were confirmed by positive differences between the water vapor and IR brightness temperature, which indicate penetration of deep convective clouds into the Tropopause, moistening the Stratosphere (Schmetz et al., 1997; Machado et al., 2009).

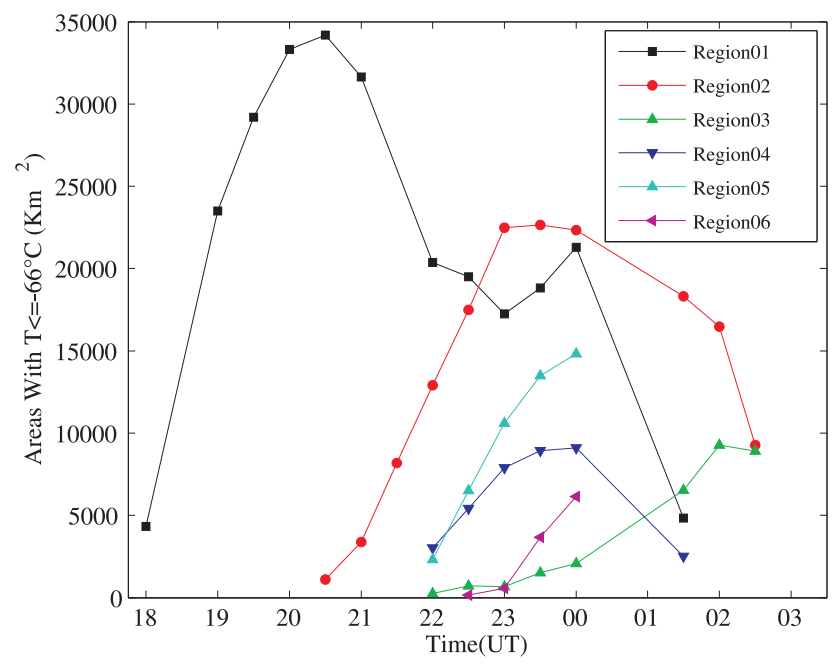

Fig. 4. Temperature profile of the atmosphere at Braslia (15.86 S, $47.93 \mathrm{~W}$ ) showing an average tropopause temperature of $-76^{\circ} \mathrm{C}$.

\subsection{Description of the spatial-temporal development of each convective region}

\subsubsection{The first night: 30 September-1 October 2005}

On this night we identified 6 regions with strong convection that were active between 23:22 UT, 30 September 2005, and 01:22 UT, 1 October 2005. This time interval was chosen to cover the excitation times estimated by Vadas et al. (2009) via reverse ray tracing of the single medium-scale gravity wave observed on this night by Taylor et al. (2009), which had a horizontal wavelength of $\lambda_{H}=145.1 \mathrm{~km}$. Vadas et al. (2009) estimated that this wave propagated eastward from two sources located $400-500 \mathrm{~km}$ southwest from the observation site and was excited at 00:40 UT and 01:20 UT, using modeled winds, or at 00:30 UT and 01:00 UT using zero winds in the ray tracing model.

Starting at the time interval 23:22-01:22 UT when the 6 regions were selected, we tracked them back in time until their initiation and forward until they were no longer present in the IR data. Table 1 shows the lifetime, initiation and termination times, and maximum extent of the convective regions, and Fig. 5 shows the temporal evolution of the Regions total cloud cover.

From the moment of its initiation, at 17:52 UT, until 19:22 UT Region 1 experienced its maximum growth rate. Within this $1.5 \mathrm{~h}$ period the general cloud cover grew by a factor of 7 and the cloud tops quickly cooled down indicating vigorous updrafts, with a grow rate estimated in $\sim 276 \mathrm{~km}^{2} / \mathrm{min}$ (Fig. 5). The number of areas with $T \leq-76^{\circ} \mathrm{C}$ per satellite image grew from one to seven, each one of them holding a convective core. The convective cores had a $\Delta T$ between $-2.0^{\circ} \mathrm{C}$ and $-8.0^{\circ} \mathrm{C}$, from a mean $T_{a v}$ of $-75.4^{\circ} \mathrm{C}$, which corresponded to tropopause overshoots 
Table 1. Convective Regions' temporal and spatial parameters, 30 September-1 October 2005.

\begin{tabular}{ccccccc}
\hline Region & Initiation & Termination & Lifetime & Time of max. extent & Max. extent & Diameter \\
\hline 1 & $17: 53 \mathrm{UT}$ & $01: 22 \mathrm{UT}$ & $7.5 \mathrm{~h}$ & $20: 22 \mathrm{UT}$ & $34198 \mathrm{~km}^{2}$ & $209 \mathrm{~km}$ \\
2 & $20: 53 \mathrm{UT}$ & $02: 22 \mathrm{UT}$ & $5.5 \mathrm{~h}$ & $23: 22 \mathrm{UT}$ & $22655 \mathrm{~km}^{2}$ & $170 \mathrm{~km}$ \\
3 & $22: 22 \mathrm{UT}$ & $02: 22 \mathrm{UT}$ & $4.0 \mathrm{~h}$ & $01: 52 \mathrm{UT}$ & $9279 \mathrm{~km}^{2}$ & $109 \mathrm{~km}$ \\
4 & $21: 52 \mathrm{UT}$ & $01: 22 \mathrm{UT}$ & $3.5 \mathrm{~h}$ & $23: 53 \mathrm{UT}$ & $9102 \mathrm{~km}^{2}$ & $108 \mathrm{~km}$ \\
5 & $21: 52 \mathrm{UT}$ & $23: 53 \mathrm{UT}$ & $2.0 \mathrm{~h}$ & $23: 53 \mathrm{UT}$ & $14819 \mathrm{~km}^{2}$ & $137 \mathrm{~km}$ \\
6 & $22: 22 \mathrm{UT}$ & $23: 53 \mathrm{UT}$ & $1.5 \mathrm{~h}$ & $23: 53 \mathrm{UT}$ & $6134 \mathrm{~km}^{2}$ & $88 \mathrm{~km}$ \\
\hline
\end{tabular}

Table 2. Convective core characteristics for Region 1, 30 September-1 October 2005.

\begin{tabular}{cccccccc}
\hline Time & Area $\left(\mathrm{km}^{2}\right)$ & Diameter $(\mathrm{km})$ & Lat/Lon $\left({ }^{\circ}\right)$ & $\Delta T(\mathrm{~K})$ & $T_{a v}(\mathrm{~K})$ & $T_{\text {core }}(\mathrm{K})$ & Overshoot $(\mathrm{m})$ \\
\hline $19: 52$ & 62.7 & 8.9 & $-20.55 /-56.52$ & -8.0 & -75.2 & -83.2 & 3127.5 \\
$20: 22$ & 92.7 & 10.9 & $-20.66 /-57.06$ & -2.2 & -75.3 & -77.4 & 333.1 \\
$20: 22$ & 46.4 & 7.7 & $-20.58 /-57.05$ & -2.2 & -75.3 & -77.4 & 333.1 \\
$20: 53$ & 62.8 & 8.9 & $-20.70 /-56.96$ & -2.4 & -75.0 & -77.4 & 333.1 \\
$21: 52$ & 125.3 & 12.6 & $-21.05 /-55.72$ & -4.7 & -75.5 & -80.2 & 1826.8 \\
$22: 22$ & 266.3 & 18.4 & $-20.86 /-55.46$ & -3.7 & -75.4 & -79.1 & 1335.5 \\
$22: 22$ & 92.6 & 10.9 & $-20.98 /-55.49$ & -3.7 & -75.4 & -79.1 & 1335.5 \\
$22: 52$ & 92.7 & 10.9 & $-20.74 /-55.21$ & -4.1 & -75.5 & -79.6 & 1579.2 \\
$22: 52$ & 83.3 & 10.3 & $-21.06 /-55.28$ & -3.0 & -75.5 & -78.5 & 1096.4 \\
$23: 22$ & 69.4 & 9.4 & $-21.07 /-55.10$ & -2.8 & -75.7 & -78.5 & 1096.4 \\
$23: 22$ & 69.4 & 9.4 & $-21.07 /-55.03$ & -2.8 & -75.7 & -78.5 & 1096.4 \\
$23: 53$ & 23.2 & 5.4 & $-20.58 /-54.94$ & -2.1 & -74.8 & -76.9 & 209.7 \\
\hline
\end{tabular}

between $200 \mathrm{~m}$ and $3100 \mathrm{~m}$. The growth of Region 1 apparently followed the dynamics of convective core activity; it reached its maximum extent of $34198 \mathrm{~km}^{2}$ at $20: 22 \mathrm{UT}$, one hour after the peak in convection. It remained convectively active until 23:22 UT, with 1-3 simultaneous convective cores, entering the decay phase afterwards. Each convective core lasted in average one image (taken at $30 \mathrm{~min}$ intervals) and their diameter varied between 5 and $18 \mathrm{~km}$. Region 1 was the longest lasting, $8 \mathrm{~h}$, the most active and complex Region. Table 2 shows several parameters of convective cores identified for Region 1.

Region 2 initiated at 20:53 UT and after $30 \mathrm{~min}$ merged with another convective region, undergoing intense growth with 2-3 simultaneously active convective cores until 22:52 UT. During this phase the region grew by a factor of 6.6 and the growth rate was estimated in $\sim 159 \mathrm{~km}^{2} / \mathrm{min}$. The mean $T_{a v}$ of Region 2 was $-75.7^{\circ} \mathrm{C}$. The convective cores $\Delta T s$ varied between $-2.3^{\circ} \mathrm{C}$ and $-4.9^{\circ} \mathrm{C}$, and the consequent overshoots were $\sim 300 \mathrm{~m}$ and $1800 \mathrm{~m}$. After 23:53 UT there was a one hour gap in the satellite data (00:2200:52 UT) and the next available image was at 01:22 UT, when the region was already dissipating. Region 2 had a lifetime of $5.5 \mathrm{~h}$ and its development also tended to follow the convective core dynamics reaching its maximum extent
30 min after the peak convective core activity. This Region was the second most active of the night, its convective cores, with 9-20 km diameter, were slightly larger than the ones in Region 1.

Region 3 started at 22:22 UT and, differently from the first two, had a very slow growth rate (Fig. 5). The 00:2200:52 UT satellite data gap did not allow the determination of the total number of convective cores of this Region. Single vigorous convective cores with an average diameter of $7 \mathrm{~km}$ occurred at 01:22 UT and 01:52 and Region 3 entered dissipation phase immediately afterwards.

Region 4 had no significant area with $T \leq-76^{\circ} \mathrm{C}$ throughout its $3.5 \mathrm{~h}$ lifetime and all convective cores were of moderate intensity. It initiated attached to Region 1 at 21:52 UT and lasted until 01:22 UT, reaching its maximum extent of $9102 \mathrm{~km}^{2}$ at 23:53 UT. The strongest convective core occurred in an area with $T_{a v}$ of $-72.6^{\circ} \mathrm{C}$, and had a $\Delta T$ of $-4.3^{\circ} \mathrm{C}$, producing an estimate overshoot of $\sim 200 \mathrm{~m}$. The weakest had a Tropopause overshoot of $30 \mathrm{~m}$.

Region 5 first showed at 21:52 UT with an already well developed area with $T \leq-76^{\circ} \mathrm{C}$ that lasted for one hour. It had a sequence of three new vigorous $7-13 \mathrm{~km}$ diameter convective cores within $30 \mathrm{~min}$ intervals during $1.5 \mathrm{~h}$. The Tropopause overshoots of the convective cores were 
estimated at $1100-2800 \mathrm{~m}$. Meanwhile, Region 5 grew by a factor of 4.6 with a growth rate of $\sim 138 \mathrm{~km} / \mathrm{min}$, then the cloud tops start to warm up. At 23:53 UT it reached its maximum extent of $14819 \mathrm{~km}^{2}$, after the one hour gap in the data the convective core had already dissipated. The general cloud cover of Region 5 also seemed to follow the convective core dynamics since it maximized $1.5 \mathrm{~h}$ after having two simultaneously active convective cores in areas with $T \leq-76^{\circ} \mathrm{C}$.

Region 6 initiated at 22:22 UT, attached to Region 5, with a slow growth during the first hour. It had only two small convective cores, with $\sim 7 \mathrm{~km}$ diameter that followed each other with a $30 \mathrm{~min}$ interval.

\subsubsection{The sprite night: $25-26$ October 2005}

On this night convection was characterized by small short lived convective cells, constantly forming and dissipating at isolated locations in a disorganized fashion. The active regions were connected by extensive warm cloud covers $\left(T \leq-50^{\circ} \mathrm{C}\right)$ formed by advected anvil material left behind from dying cells. Three typical thunderstorms produced TLEs that were observed from 22:56 UT to 01:54 UT. A total of 11 events were recorded, 9 were sprites and 2 were halos. In the beginning of the night 2 sprites and one halo occurred over the State of Mato Grosso, above a thunderstorm $\sim 480 \mathrm{~km}$ west of the optical site. BrasilDAT detected one $-\mathrm{CG}$ of $-65.7 \mathrm{kA}$ preceding one of the sprites in $193 \mathrm{~ms}$ and at $\sim 77 \mathrm{~km}$ distance from it. Since negative sprites are rare and the network had low detection efficiency for this thunderstorm, it was not possible to determine if this was the causative discharge. A warm cloud band connected the southern portion of the first storm to the thunderstorm that produced the second halo and another 4 sprites.

The third sprite producing storm of the evening was closer to the observation site. It was east of the second thunderstorm, over the State of Goiás, and produced the remaining sprites during the last hour of the observation period. The sprites, much closer to the optical site, $\sim 300 \mathrm{~km}$, were often groups of columns that lasted at least $33 \mathrm{~ms}$, as shown on Figs. 6 and 7. Two sprites from the third thunderstorm did have their causative +CGs detected by BrasilDAT, the first $+\mathrm{CG}$ had a peak current of $77.1 \mathrm{kA}$ and occurred $2 \mathrm{~ms}$ before the sprite at $\sim 21 \mathrm{~km}$ from it. The second $+\mathrm{CG}$, with $47.8 \mathrm{kA}$ peak current, stroke the ground at $\sim 57 \mathrm{~km}$ from the sprite preceding it in $18 \mathrm{~ms}$.

All three TLE producing storms on the night of 25-26 October 2005 were small and produced few events. Several observations in different locations of the world, e.g. Europe (Neubert et al., 2001; Taylor et al., 2000, Japan (Fukunishi et al., 2001), and Peru (Sentman et al., 1995; Moudry et al., 1997), had already shown that small thunderstorms can also produce sprites in modest number. Several years of observations in the central US and a few observations in South America show that sprites and other TLEs are more commonly observed above large mesoscale systems, which can

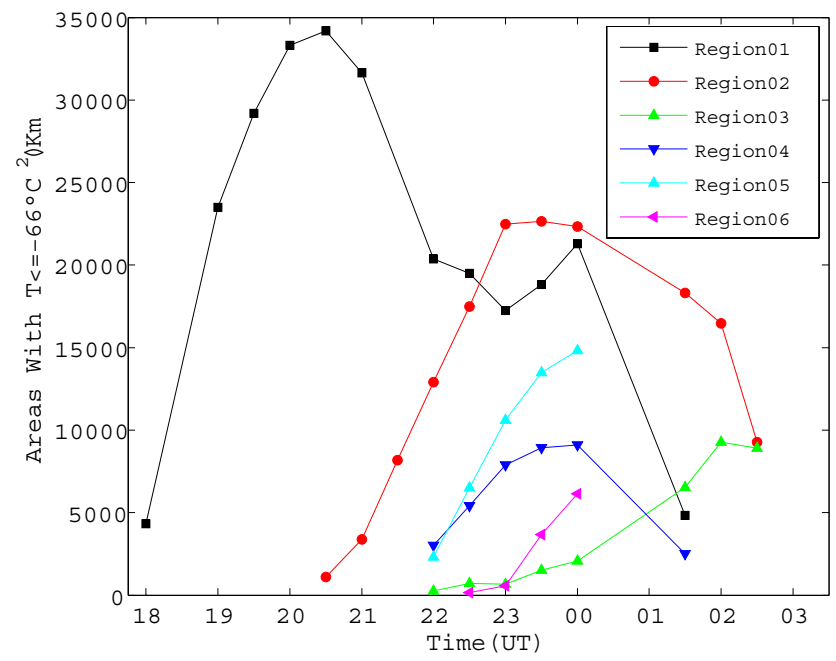

Fig. 5. Overall cloud cover $\left(T<-66^{\circ} \mathrm{C}\right)$ temporal evolution of 30 September-1 October 2005 convective Regions.

produce hundreds of events (Lyons et al., 1996; Thomas et al., 2007; São Sabbas et al., 2007).

In this study we describe for the first time the convective characteristics of three small TLE producing thunderstorms present in satellite IR images on 25-26 October 2005. We identified 5 active convective Regions $\left(T \leq-66^{\circ} \mathrm{C}\right)$ during sprite and halo observation, between 22:52-01:52 UT. They were tracked backward in time until their initiation and forward until their termination, and numbered 7-11, to follow the sequence from the first night. The Regions lifetime, initiation and termination times, and maximum extent are shown on Table 3. Figure 8 shows the Regions general cloud cover temporal evolution.

The first storm had three convective Regions that were active at the time sprites were observed, Region 7, 8 and 9. The second storm had a single convective region, Region 10 , which had already decayed when TLEs were observed. The TLEs were possibly produced by end of storm oscillation (EOSO) strong CGs (Lyons et al., 1996). Region 11 formed the third storm. Figure 3 shows the Regions locations at 22:52 UT. As typical of this night, they emerged from left over cloud material from dying convective cells, and were succeeded by new cells "born" within their remaining clouds. This continuous cell renewal kept the thunderstorms active for several hours longer than the lifetime of the individual convective regions. Only Regions 7 and 8 from the first thunderstorm had cloud tops areas with $T \leq-76^{\circ} \mathrm{C}$ and developed vigorous convective cores during their growth. Region 9, also from the first storm, and the Regions forming the other two TLE producing storms did not have cloud tops with $T \leq-76^{\circ} \mathrm{C}$, such that all convective cores were of moderate intensity and $T_{a v}$ was calculated using a threshold of $T \leq-70^{\circ} \mathrm{C}$. 

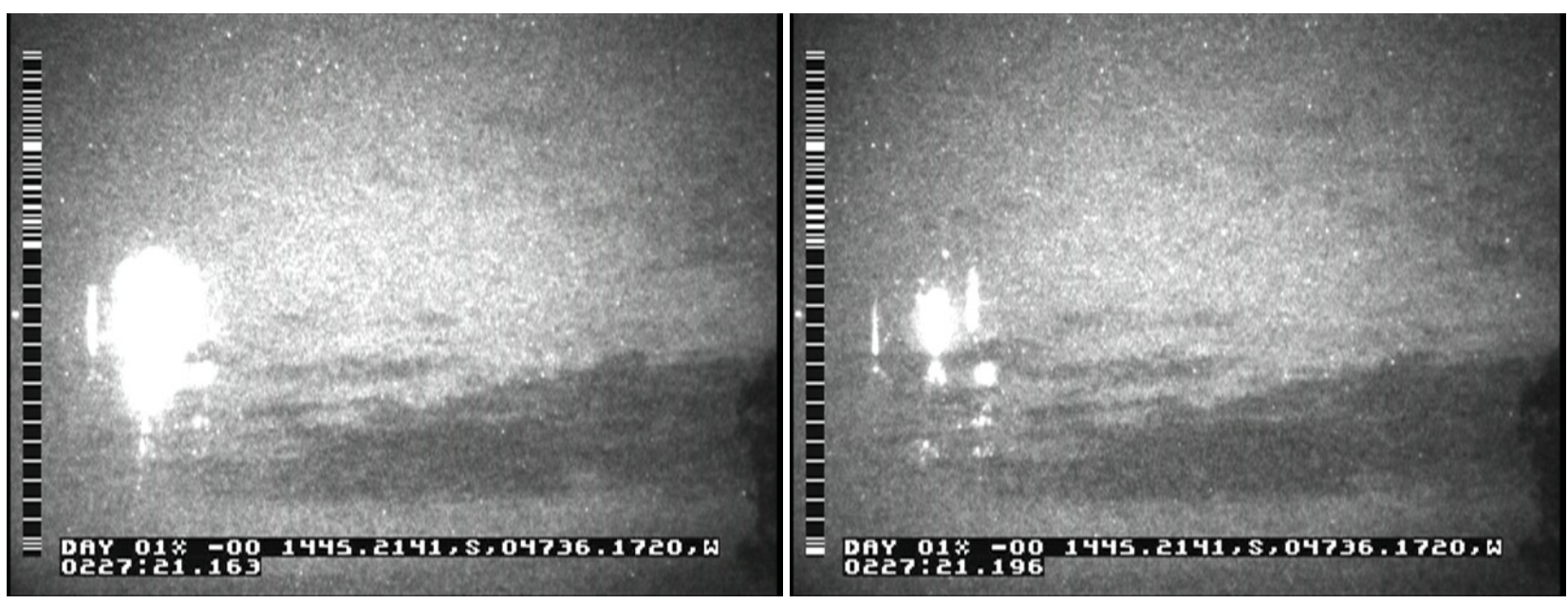

Fig. 6. Group of columns sprites with $33 \mathrm{~ms}$ duration produced by the third thunderstorm locate in Goiás State.
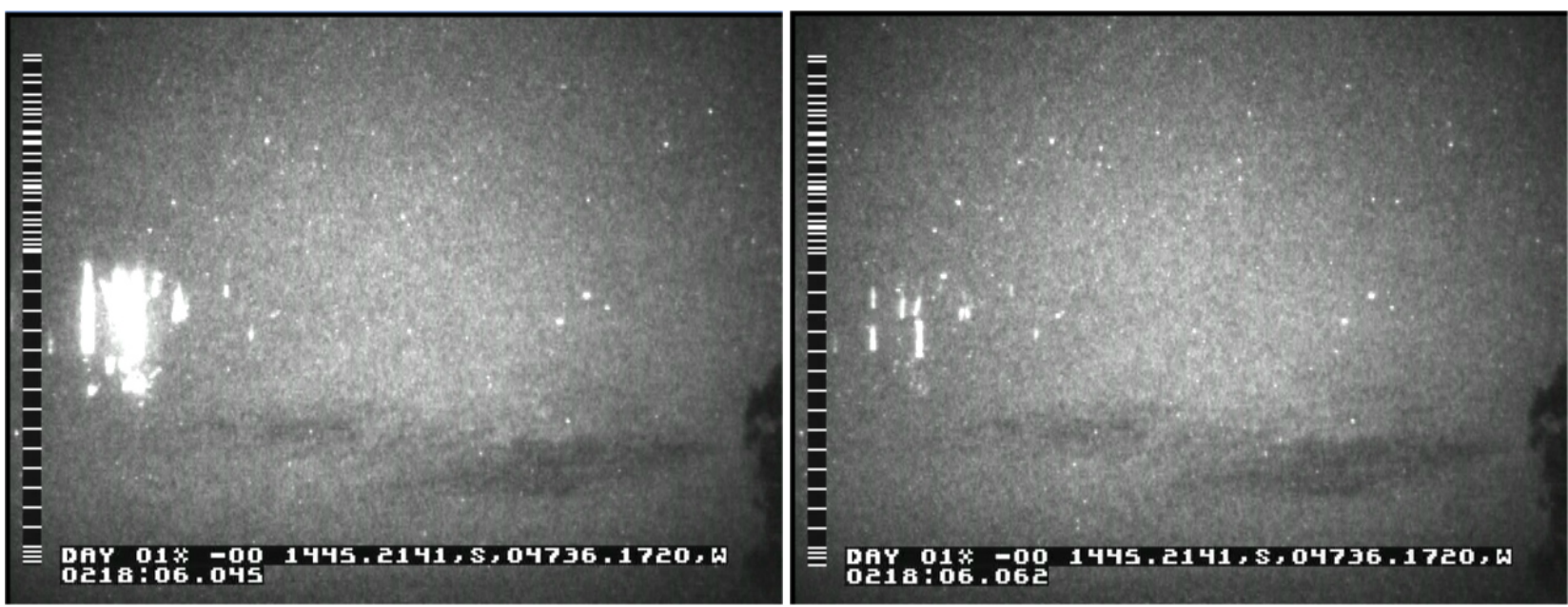

Fig. 7. A second sprite group that lasted one frame, i.e. $33 \mathrm{~ms}$, observed above the same storm.

Region 7 initiated at 18:22 UT with a $\sim 14 \mathrm{~km}$ diameter convective core inside an area with $T \leq-76^{\circ} \mathrm{C}$. During the first $1.5 \mathrm{~h}$ the cloud tops warmed up and the Region decayed in size. Then, Region 7 entered a growth phase, the general cloud cover expanded at rate of $\sim 83 \mathrm{~km}^{2} / \mathrm{min}$, and the cloud tops got colder showing up to 5 simultaneous active convective cores at 21:22 UT. The convective cores were in an area with mean $T_{a v}$ of $-76.8^{\circ} \mathrm{C}$ and had overshoots of 1100 $2600 \mathrm{~m}$. Region 7 reached a maximum extent of $18670 \mathrm{~km}^{2}$ $30 \mathrm{~min}$ later and started to decay afterwards having a total lifetime of $4 \mathrm{~h}$. The development of this Region also shows a relationship with the number of active vigorous convective cores and, consequently, the level of convective activity.

Region 8 initiated when Region 7 had its peak convective activity, at 21:22 UT. It became attached to Region 7 after 30 min. Region 8 had between 2 and 3 simultaneous active convective cores with diameters of $6-10 \mathrm{~km}$ and overshoots of 1600-2600 $\mathrm{m}$ during the first $1.5 \mathrm{~h}$ of its lifetime, growing $\sim 80 \mathrm{~km}^{2} / \mathrm{min}$. The general cloud cover continued to grow due to anvil advection, even though the cloud tops started to warm up. It was possible to identify three simultaneously active convective cores of moderate intensity applying the $T \leq-70^{\circ} \mathrm{C}$ threshold for $T_{a v}$ before Region 8 decayed.

Region 9 was extremely small, with $1210 \mathrm{~km}^{2}$, and lasted for only one hour. It was the one closest to the sprites and halos produced by the first thunderstorm, which was composed by Regions 7, 8 and 9, and produced intense lightning discharges registered by BrasilDAT network within a few seconds from the sprites. Its coldest cloud top temperature reached $-74.2^{\circ} \mathrm{C}$, and the region had a single moderate convective core with $\sim 10 \mathrm{~km}$ diameter. 
Table 3. Convective Regions' temporal and spatial parameters, 25-26 October 2005.

\begin{tabular}{ccccccc}
\hline Region & Initiation & Termination & Lifetime & Time of max. extent & Max. extent & Diameter \\
\hline 7 & $18: 52 \mathrm{UT}$ & $22: 52 \mathrm{UT}$ & $4.0 \mathrm{~h}$ & $21: 52 \mathrm{UT}$ & $18686 \mathrm{~km}^{2}$ & $154 \mathrm{~km}$ \\
8 & $21: 22 \mathrm{UT}$ & $23: 22 \mathrm{UT}$ & $2.0 \mathrm{~h}$ & $23: 22 \mathrm{UT}$ & $13859 \mathrm{~km}^{2}$ & $133 \mathrm{~km}$ \\
9 & $22: 52 \mathrm{UT}$ & $23: 22 \mathrm{UT}$ & $0.5 \mathrm{~h}$ & $22: 52 \mathrm{UT}$ & $1210 \mathrm{~km}^{2}$ & $39 \mathrm{~km}$ \\
10 & $22: 22 \mathrm{UT}$ & $23: 22 \mathrm{UT}$ & $1.0 \mathrm{~h}$ & $22: 22 \mathrm{UT}$ & $5904 \mathrm{~km}^{2}$ & $87 \mathrm{~km}$ \\
11 & $22: 52 \mathrm{UT}$ & $01: 52 \mathrm{UT}$ & $3.0 \mathrm{~h}$ & $23: 54 \mathrm{UT}$ & $4605 \mathrm{~km}^{2}$ & $77 \mathrm{~km}$ \\
\hline
\end{tabular}

Region 10 was a small region associated with sprite and halo production of the second storm. It had 3 simultaneously active convective cores of moderate intensity and average $5 \mathrm{~km}$ diameter within its first hour of existence. The convective cores were in an area with mean $T_{a v}$ of $-72.3^{\circ} \mathrm{C}$ and one of them was strong enough to overshoot $\sim 200 \mathrm{~m}$. After that the region started to decay.

Region 11 belonged to the thunderstorm that produced more sprites. This Region had only moderate convective cores with overshoots of $\sim 90 \mathrm{~m}$. During its $3 \mathrm{~h}$ lifetime it had an average of 2 simultaneous active convective cores each with diameter between 5 and $10 \mathrm{~km}$. The Region initiated at 22:52 UT and $2 \mathrm{~h}$ later produced 4 sprites within $\sim 30 \mathrm{~min}$.

\subsection{Lightning activity}

We performed an analysis of the Regions' lightning activity in relation with the cloud top temperatures. The parameters investigated are number of positive and negative cloud-toground ( $+/-$ CGs), and the average peak current associated with a given temperature in time. Since cloud electrification is also related to the convective activity, the objective was to have another parameter to gauge the level of convection inside the regions.

The locations of the sensors operating in the Brazilian Lighting Detection Network, BrasilDAT, are shown on Fig. 9. The figure also shows the modeled detection efficiency of the network (Naccarato, 2006; Naccarato et al., 2006) and approximate locations of the convective regions at 23:53 UT for the first night and at 22:52 UT for the second night. Due to the scale, the lowest detection efficiency displayed on the figure is $30 \%$, however, for locations further than $600 \mathrm{~km}$ from the network the efficiency drops to $10 \%$ or less. In this case, one would expect to detect only the strongest discharges and that is exactly what we observe for Regions 2, 3, 7, 8, and 9, few discharges with very large peak current (not shown). Region 11 was in an area with $40 \%$ detection efficiency but presented the same pattern, showing that $40 \%$ is still a low lightning detection. If the lightning location is more than $400 \mathrm{~km}$ from the network, the sensors detected both the ground wave and the low frequency (LF) electromagnetic wave that undergoes reflections on the ionosphere, which makes the polarity determination uncertain.

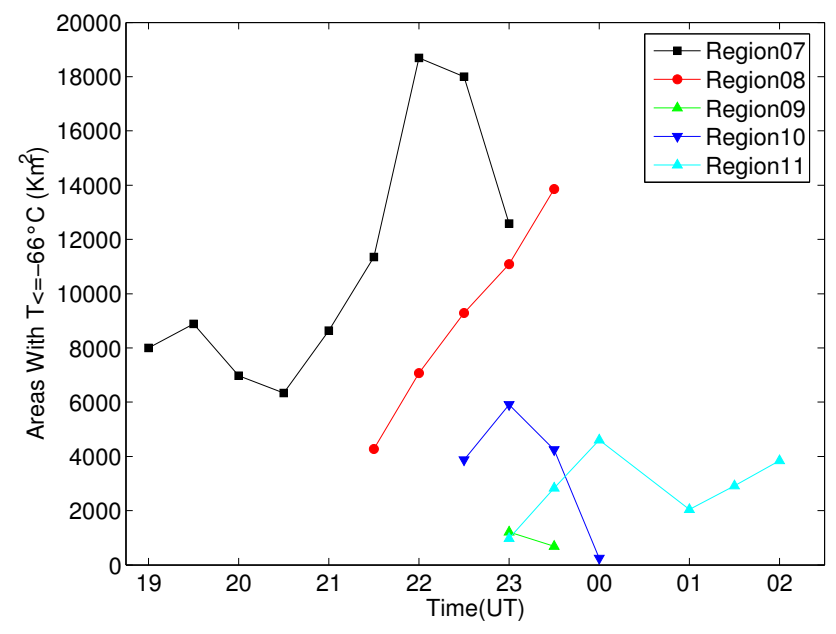

Fig. 8. Overall cloud cover $\left(T<-66^{\circ} \mathrm{C}\right)$ temporal evolution of $25-$ 26 October 2005 convective regions.

Regions 1,4 and 10 were within this limitation range. Regions 5 and 6 were the only ones close enough to the network to have a detection efficiency $\geq 70 \%$.

For Regions 5 and 6 we could analyze the relationship between lightning activity and the cloud top temperatures, and relate that with convection. We expected a higher lightning rate, of both polarities, at the convective cores, represented by the lowest $T$, due to the stronger drafts responsible for electrification. That is exactly what was observed on Figs. 10a and 11a for Region 5 negative and positive CG occurrence rates, respectively.

The highest -CG rates of Region 5 occurred in areas with the lowest temperatures, where the convective cores were located. There was a gradual temperature increase from $-78^{\circ} \mathrm{C}$ to $-72^{\circ} \mathrm{C}$ and accompanying reduction of the lighting rate were during the lifecycle of the region, which initiated with very strong convection but quickly decayed. Figure $10 \mathrm{~b}$ shows that the discharges with high occurrence rates had an average peak current of $-30 \mathrm{kA}$, representing the bulk of $-\mathrm{CG}$ peak current distribution, centered on -20 to $-30 \mathrm{kA}$. There is a clear gradient going from low peak currents associated with the coldest cloud tops, to high peak currents associated with warm cloud tops $\left(T_{c} \geq-62^{\circ} \mathrm{C}\right)$. 


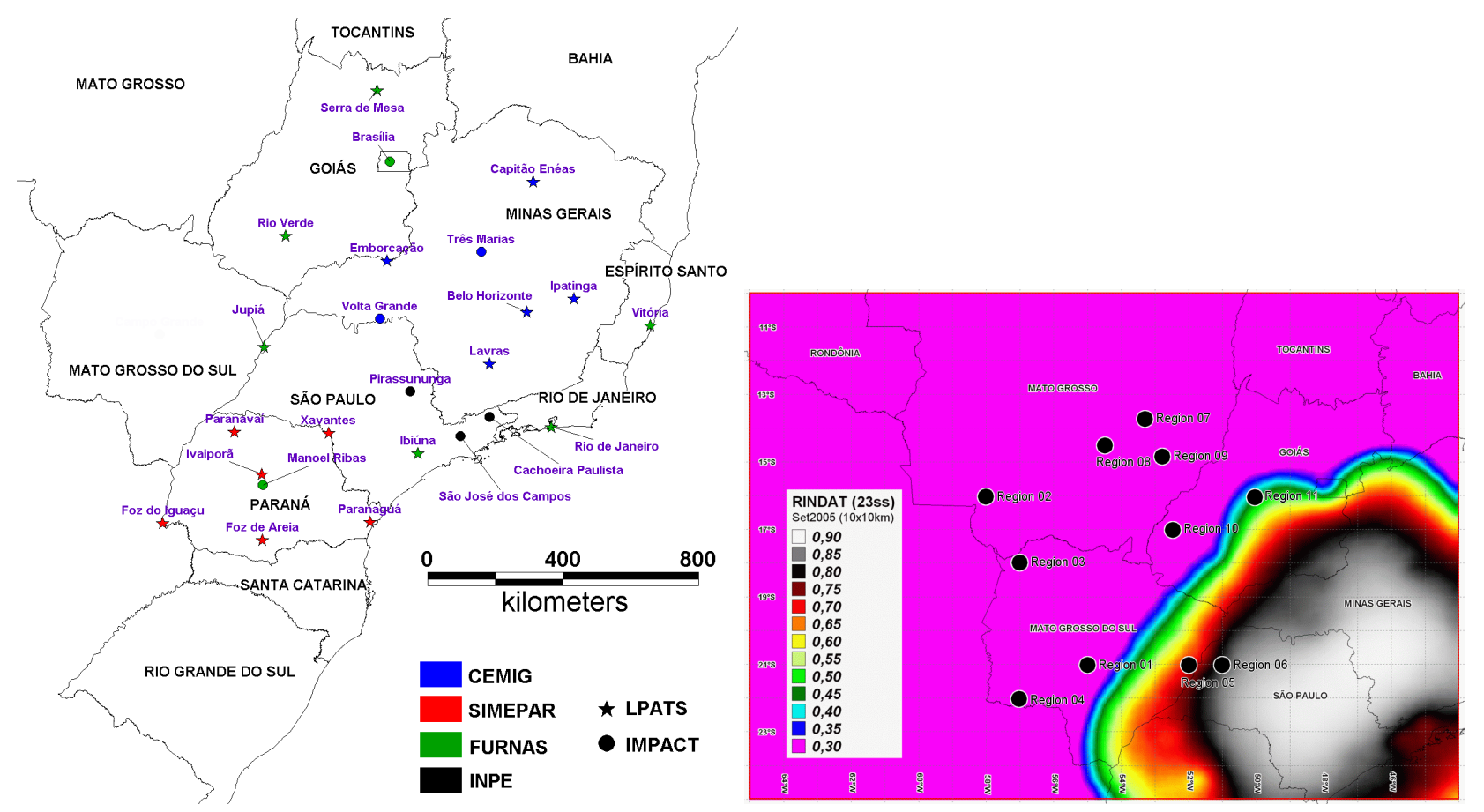

Fig. 9. Location of BrasilDAT sensors on the left, and modeled detection efficiency showing approximated locations of the convective region centers at 23:53 UT, on the right (adapted from Naccarato, 2006).

Figure 11 shows a strong $+\mathrm{CG}$ activity in areas with temperatures $\sim 2^{\circ} \mathrm{C}$ warmer than the $-\mathrm{CG}$ areas, such that $+\mathrm{CGs}$ seem to occur at the "outskirts" of the convective cores. Also, a clear peak current gradient is not present showing a different behavior between negative and positive discharges. Region 6 spectrograms (not shown) show a similar behavior for discharges of both polarities. Outside the convective cores, where the drafts are weaker and therefore the cloud tops are warmer, the charged cloud material advected from convective cores do have a chance to form more extensive charge layers that allow for high peak current discharges. Sprites and other TLEs occur predominantly above these regions, with stratiform characteristics. They tend to have a positive charge "reservoir" that favors the occurrence of +CGs removing enough charge to produce the intense mesospheric electric fields that generate sprites/TLEs.

\section{Discussion}

The dry to wet season transition that occurs between the months of September and November in the central part of Brazil provided for distinctive convective patterns on the two nights of the campaign analyzed here. The first night was characterized by more localized isolated convection, with the presence of a few small convective systems. The second night, however, was dominated by "popcorn" like convection, i.e. numerous small convective cells embebed in an ex- tense cloud cover with higher temperatures. The main difference in the synoptic meteorological scenario was that there was more preciptable water available to initiate convection on the second night.

We developed a methodology to identify the convective cores active on the 11 convective regions present in both nights analyzed, to estimate their horizontal scales, Tropopause overshoot, and to quantify their intensity, determined by the temperature difference $(\Delta T)$ between $T_{\text {core }}$ and $T_{a v}$ of surrounding anvils. Applying this methodology the estimated diameters ranged from 5 to $20 \mathrm{~km}$, in good agreement with values available in the literature (Heymsfield and Blackmer Jr., 1988; Cotton and Anthes, 1989). Higher temperature deficits $\Delta T$ tended to produce larger convective cores, and the size of the convective cores showed a 57\% correlation with $\Delta T$ (excluding one outlier), similar to what was found by Heymsfield and Blackmer Jr. (1988). The convective cores average duration was $30 \mathrm{~min}$.

All regions on the first night (except for Region 4) and Regions 7 and 8 of the second night had cloud top areas with $T \leq-76^{\circ} \mathrm{C}$ in their growth phase. That was the estimated temperature for the Tropopause, which was at an altitude of $\sim 15200 \mathrm{~m}$. The mean $T_{a v}$ for the cloud tops in this phase was $-75.6^{\circ} \mathrm{C}$ for the first night and $-76.7^{\circ} \mathrm{C}$ for the second night, such that the coldest cloud tops surrounding the convective cores corresponded to average altitudes of $15070 \mathrm{~m}$ and $15320 \mathrm{~m}$. The negative deviations from $T_{a v}$, between 

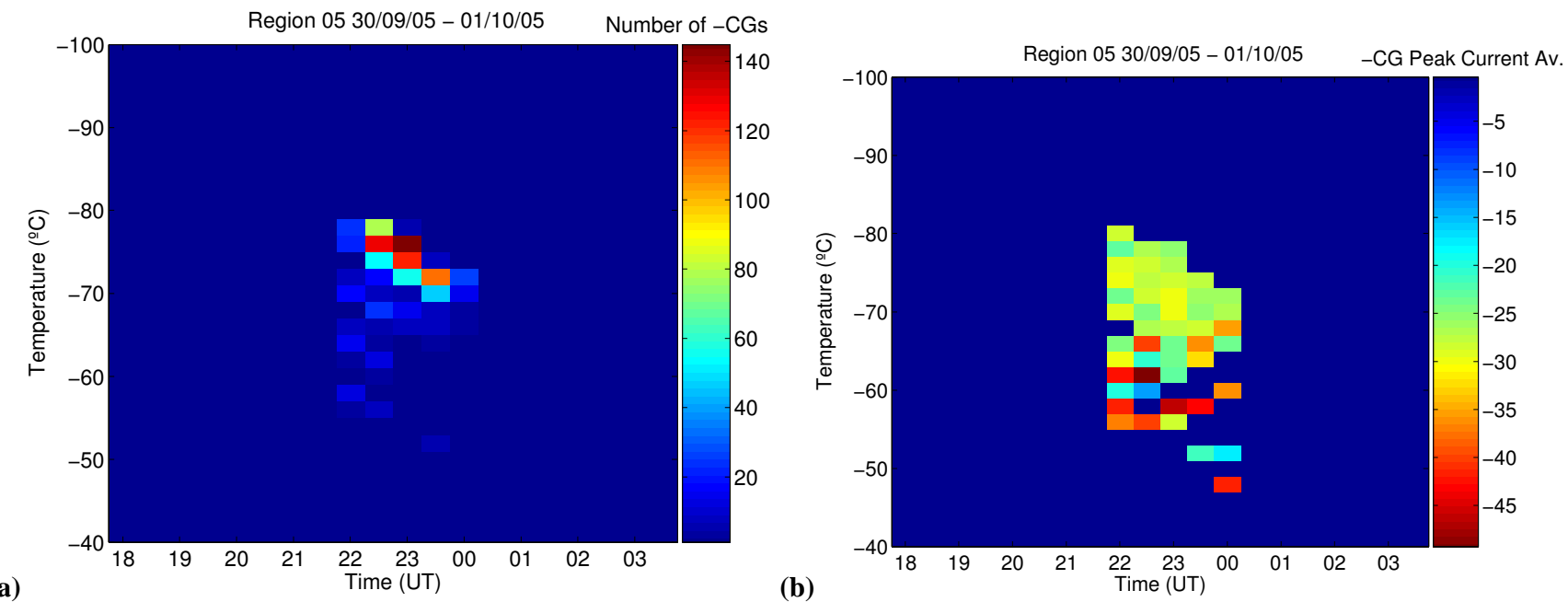

Fig. 10. Temporal spectrograms of CG occurrence rate (a) and peak current (b) as a function of cloud top temperature, 30 September-1 October 2005.
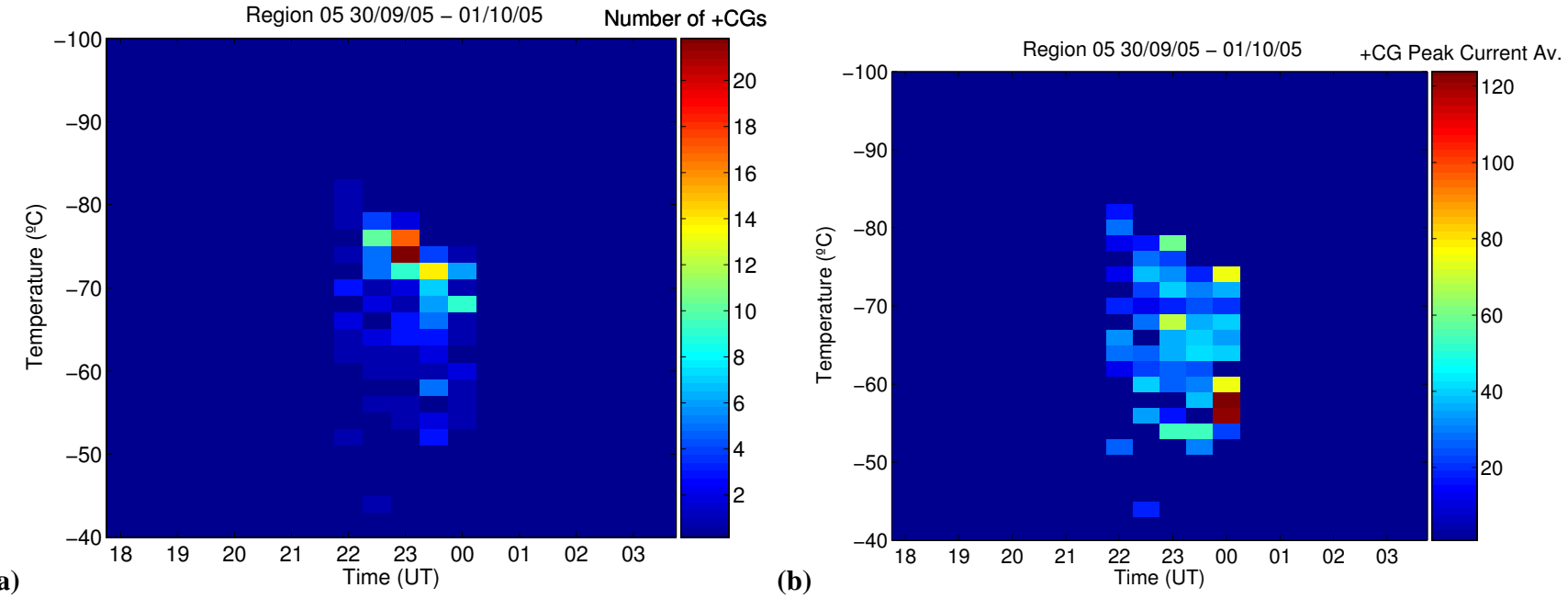

Fig. 11. Temporal spectrograms of $+\mathrm{CG}$ occurrence rate (a) and peak current (b) as a function of cloud top temperature, 30 September-1 October 2005.

$-2.0^{\circ} \mathrm{C}$ and $-8.0^{\circ} \mathrm{C}$, indicated the presence of strong convective cores locating possible GW convective sources. The coldest cloud tops of Region 4 from the first night and Regions 9 to 11 had mean $T_{a v}$ of $-72.2^{\circ} \mathrm{C}$ and $-71.6^{\circ} \mathrm{C}$, respectively, with $\Delta T$ between $-1.9^{\circ} \mathrm{C}$ and $-5.3^{\circ} \mathrm{C}$ showing only moderate convective cores.

The vigorous convective cores, likely to produce gravity waves, had cloud tops overshoots estimated at 200-3100 m, and the moderate at $80-300 \mathrm{~m}$, respectively. The overshoot of vigorous convective cores on Fig. 12 shows that the convective cores predominantly rose $1000-1200 \mathrm{~m}$ above the Tropopause. The overshoot values presented here could be over estimated but as first order approximations provide a quantitative measure of the intensity of the convective cores analyzed. The $\Delta T$ variation from the average cloud tops that locate the convective cores and the estimated overshoot are important parameters to determine the gravity wave spectra generated by the convective cores and how far into the Thermosphere the waves may propagate, since they are related to the updraft velocities.

Three distinct types of convective Regions were identified. The first type was composed by Regions 1, 2, 5, 7 and 8 , and was the dominant type. It presented a fast initial growth, with a growth rate that varied from $\sim 83 \mathrm{~km}^{2} / \mathrm{min}$ for the smaller Regions to $\sim 276 \mathrm{~km}^{2} / \mathrm{min}$ for Region 1, the largest one. This intense growth was associated with having 


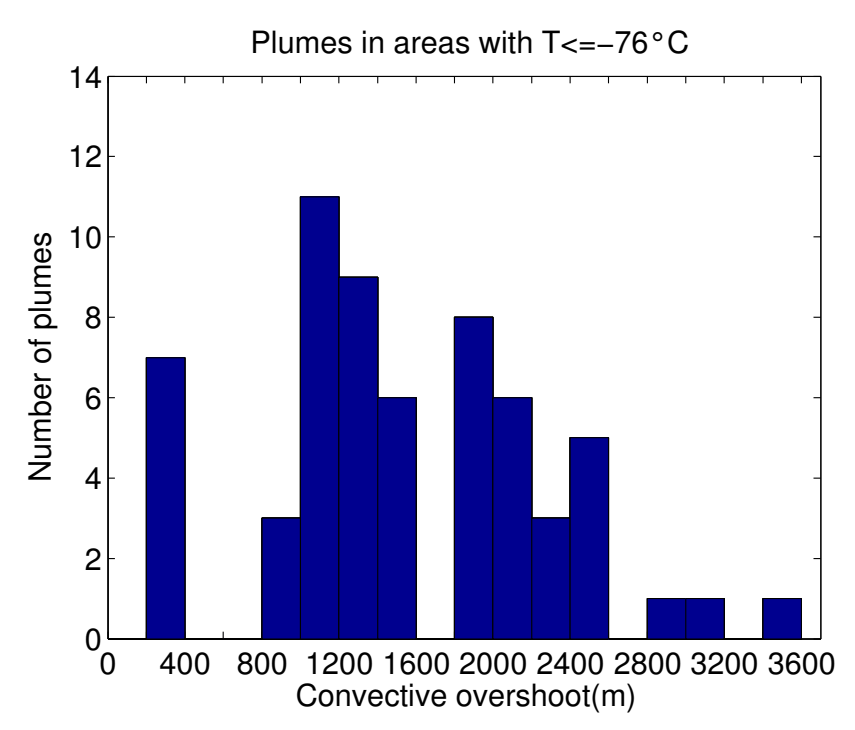

Fig. 12. Convective overshoot distribution for vigorous convective cores, i.e. convective cores in areas with $T \leq-76^{\circ} \mathrm{C}$.

between 3 and 7 vigorous simultaneously active convective cores with $\Delta T \geq-2.6^{\circ} \mathrm{C}$. These regions reached their maximum extent within $30 \mathrm{~min}$ to $1 \mathrm{~h}$ from the maximum convective core activity and in most cases enter the decay phase immediately after that.

The second type, formed by Regions 3 and 4, had a slow growth and their general cloud cover did not developed areas larger than $9300 \mathrm{~km}^{2}$. Region 3 did not have more than one vigorous convective core active at a given time and Region 4 only had one moderate convective core strong enough to overshoot the Tropopause in $200 \mathrm{~m}$.

The third type was formed by the small Regions associated with TLE production, Regions 9, 10 and 11. All convective cores were of moderate intensity and only three of them were able to overshoot the Tropopause in $\sim 90 \mathrm{~m}$ and $\sim 200 \mathrm{~m}$. The lifetime of these regions varied between $30 \mathrm{~min}$ and $3 \mathrm{~h}$ and the largest one reached $\sim 1210 \mathrm{~km}^{2}$. Except for Regions 7 and 8 , which belonged to the first type, the convective activity of the TLE producing regions was weak, which possibly accounts for the low number of events produced by each thunderstorm. The sprites associated with Region 10 were produced when the region had already dissipated and could be an example of the end of storm oscillation (EOSO) capable of producing + CGs strong enough to generate sprites (Lyons et al., 1996).

The spatial-temporal evolution of the Regions analyzed suggests that their development was closely related to the dynamics of the convective core activity. The dynamics was defined by the number of convective cores active at a given image, their size and intensity $(\Delta T)$. A large number of simultaneously active convective cores and large $\Delta T$ in areas with $T \leq-76^{\circ} \mathrm{C}$ were associated with quick vertical development and high growth rates of the Region. Therefore the number of convective cores, their size and $\Delta T$ may provide a quantitative measure of the level of convection inside a thunderstorm.

Convection is also responsible for thunderstorm electrification and the analysis of the relationship between the cloud top temperatures and lightning activity of Regions 5 and 6 provided further parameters to evaluate the intensity of the convective activity inside the thunderstorms. The areas with lowest $T$, where the convective cores are located, had the highest $-\mathrm{CG}$ occurrence rates, which were produced by discharges with the lowest average peak currents $(-30 \mathrm{kA})$ composing the bulk of the peak current distribution. The peak current averages gradually increased towards areas with higher $T$, showing a clear gradient.

The high incidence of low peak current discharges at areas with cold cloud tops, representing the convective cores, can be interpreted as a direct result of the intense convective activity in these areas (Nacarato, 2006; Nacarato et al., 2006). The same strong drafts responsible for the creation of large amounts of charges, through the continuous cloud particles collisions, also inhibit the charge accumulation necessary for the occurrence of intense -CGs with high peak current. Then, the convective cores are characterized by a high incidence of low peak current -CGs and are at the same time responsible for the bulk of $-\mathrm{CG}$ population. Consequently, locating the "spots" where low peak current -CGs concentrate may be an alternative way to identify convective cores within thunderstorms. The number of such spots and their inherent lighting rate may also provide an independent parameter to gauge the level of convection inside a convective core.

\section{Conclusions}

We characterize the spatial-temporal development of sprite and gravity wave convective sources present on GOES IR images of South America on the night of 30 September to 1 October and 25-26 October 2005, part of the SpreadFEx campaign. We also developed a technique to identify convective cores capable of exciting gravity waves and estimate their size, duration, intensity and Tropopause overshoot. The relationship between the $+/-$ CG occurrence rate and peak current and cloud top temperatures was also investigated to help locating the convective cores. The resulting temporal, spatial and intensity scales can be used as input empirical parameters to simulate gravity waves excitation by convective cores and their propagation into the upper atmosphere. A total of 11 thunderstorms convective Regions from both nights were analyzed. Besides possible gravity wave sources on 25-26 October 2005, Regions 7 to 11 were associated with sprite and halo production by 3 different thunderstorms. The main results are summarized below:

1. The SpreadFEx campaign in 2005 was conduced between the months of September and November, during 
the dry to wet season transition in central Brazil, where deep convection capable of exciting gravity waves was located. The synoptic scenario was characterized by Large Scale Atmospheric Rossby Waves producing extra tropical cyclone genesis over Atlantic Ocean, which advected moisture from the Amazon generating deep convection in central Brazil, and by cold fronts propagating inland.

2. The Tropopause estimated temperature was $-76^{\circ} \mathrm{C}$ and the corresponding altitude was $\sim 15200 \mathrm{~m}$, based on atmospheric soundings.

3. The vigorous convective cores capable of generating strong gravity waves were located in areas with cloud top temperatures $\leq-76^{\circ} \mathrm{C}$, with temperature deficits of $\Delta T-2.0^{\circ} \mathrm{C}$ to $-8.0^{\circ} \mathrm{C}$ from those areas averages. They produced typical Tropopause overshoots in the range of 200-3100 m, with a distribution overshoot showing a peak at $1000-1200 \mathrm{~m}$.

4. Moderate convective cores were located in areas with cloud top $-76^{\circ} \mathrm{C} \leq T \leq-70^{\circ} \mathrm{C}$, had $\Delta T s$ of $-1.9^{\circ} \mathrm{C}$ to $-5.3^{\circ} \mathrm{C}$ and overshoots between $80-300 \mathrm{~m}$.

5. Most convective cores did not last longer than one satellite image, taken in $30 \mathrm{~min}$ intervals, and had typical diameters of 5-20 km. The convective cores sizes had a $57 \%$ correlation with their $\Delta T$.

6. Fast vertical development and high horizontal growth rates were associated with a large number of vigorous simultaneously active convective cores with large $\Delta T s$ showing that the vigorous convective cores dynamics seemed to govern the spatial-temporal development of thunderstorm convective Regions analyzed.

7. Convective cores were characterized by a high incidence of low peak current -CGs that forms the bulk of $-\mathrm{CG}$ population. An alternative way to identify convective cores within thunderstorms may be locating where low peak current - CGs concentrate.

8. A total of 11 Transient Luminous Events, including 9 sprites and 2 halos were produced by three different thunderstorms on the second night. Two sprites had their causative +CGs recorded by the BrasilDAT network. At the time of sprite production the first storm had 3 active convective Regions, two of which had fast vertical and horizontal developments due to the presence of vigorous convective cores, and one extremely small Region with only moderate convection. The other two storms had a single small convective Region with moderate activity. The low TLE production could be due to the low level of convection, i.e. small areas with deep convection, and consequent low thunderstorm electrification.
Acknowledgements. The authors would like to thank Edivan Bataglin, manager of Fazenda Isabel in Goiás, for making available all the farm infra-structure necessary to set up the São João d'Aliana observation site. Thanks to the Mayor House and House of Representatives of São João d'Aliana, especially to Julio Sempere and Nilson Deodoro Cândido for all the logistical support during the campaign. Thanks to José Leonardo Ferreira from University of Braslia for the support in preparation for the field campaign. We also would like to thank CPTEC for providing the GOES IR imagery used. Thanks to Nelson Jesus Ferreira from INPE, and Carlos Augusto Morales Rodriguez from University of São Paulo, for useful discussions about the meteorological aspects of this work. FAPESP grant 04/12350-7, DEELUMINOS Project, and INPE supported this work and provided partial support for the SpreadFEx field program, mainly supported by NASA grants NNH04CC67C and NAS5-02036.

Topical Editor U.-P. Hoppe thanks two anonymous referees for their help in evaluating this paper.

\section{References}

Abdu, M., Kherani, E. A., Batista, I. S., de Paula, E. R., and Fritts, D. C.: Gravity wave influences on plasma instability growth rates based on observations during the Spread F Experiment (SpreadFEx), Ann. Geophys., in press, 2009.

Adler, R. F. and Fenn, D. D.: Satellite data, J. Appl. Meteorol., 18 , 502-517, 1979.

Cotton. W. R. and Anthes, R. A.: Storm and Cloud Dynamics, Academic Press, 880 pp., 1989.

Cummins, K. L., Murphy, M. J., Bardo, E. A., Hiscox, W. L., Pyle, R. B., and Pifer, A. E.: A combined TOA/MDF technology upgrade of U.S. National Lightning Detection Network, J. Geophys. Res., 103, 9035-9044, 1998.

Fovell, R. G. and Ogura, Y.: Effect of the vertical wind shear on numerically simulated multicell storm structure, J. Atmos. Sci., 46, 3144-3176, 1989.

Fritts, D. C. and Vadas, S. L.: Gravity wave penetration into the thermosphere: sensitivity to solar cycle variations and mean winds, Ann. Geophys., 26, 3841-3861, 2008, http://www.ann-geophys.net/26/3841/2008/.

Fritts, D. C., Abdu, M. A., Batista, B. R., Batista, I. S., Batista, P. P., Buriti, R., Clemesha, B. R., Dautermann, T., de Paula, E., Fechine, B. J., Fejer, B., Gobbi, D., Haase, J., Kamalabadi, F., Laughman, B., Lima, P. P., Liu, H.-L., Medeiros, A., Pautet, D., Riggin, D. M., Sao Sabbas, F., Sobral, J. H. A., Stamus, P., Takahashi, H., Taylor, M. J., Vadas, S. L., and Wrasse, C.: The Spread F Experiment (SpreadFEx): Program overview and first results, Earth Planets Space, in press, 2009a.

Fritts, D. C., Abdu, M. A., Batista, B. R., Batista, I. S., Batista, P. P., Buriti, R., Clemesha, B. R., Comberiate, J., Dautermann, T., de Paula, E., Fechine, B. J., Fejer, B., Gobbi, D., Haase, J., Kamalabadi, F., Laughman, B., Lima, P. P., Liu, H.-L., Medeiros, A., Pautet, D., São Sabbas, F., Sobral, J. H. A., Stamus, P., Takahashi, H., Taylor, M. J., Vadas, S. L., and Wrasse, C.: Overview and Summary of the Spread F Experiment (SpreadFEx), Ann. Geophys., in review, 2009b.

Fukunishi, H., Takahashi, Y., Adachi, T., and Miyasato, R.: Characteristics of sprites and Elves observed in winter above Japan, 
Proc. IAGA-IASEI Joint Scientific Assembly, Hanoi, Vietnam, p. 98, August 2001.

Heymsfield, G. M. and Blackmer Jr., R. H.: Satellite-observed charactistics of Midwest severe thunderstorm anvils, Mon. Weather Rev., 116, 2200-2224, 1988.

Kherani, A., Abdu, M., Paula, E., et al.: 3-D simulations of plasma instabilities employing SpreadFEx estimates of gravity wave parameters for seeding conditions, Ann. Geophys., in review, 2009.

Lane, T. P., Reeder, M. J., and Clark, T. L.: Numerical modeling of gravity waves generated by deep tropical convection, J. Atmos. Sci., 58, 1249-1274, 2001.

Lyons, W. A.: Sprite observations above the U.S. High Plains in relation to their parent thunderstorm systems, J. Geophys. Res., 101, 29641-29652, 1996.

Machado, Luiz, A. T., Lima, W. F. A., Pinto Jr., O., and Morales, C. A.: Relationship between Cloud-Ground Lightning and Penetrative Clouds: A Multi-channel Satellite Application, Atmos. Res., submitted, 2009.

Moudry, D. R., Heavner, M. J., Sentman, D. D., and Wescott, E. M.: Sprites over small storms, EOS Trans. AGU, 78(46), Fall Meet. Suppl., Abstract A22C-07, 1997.

Naccarato, K. P.: Analysis of the lightning characteristics in the Southeast Region of Brazil, São José dos Campos, 362 p., INPE14083-TDI/1069, PhD Dissertation (in portuguese), Instituto Nacional de Pesquisas Espaciais, São José dos Campos, 2006.

Naccarato, K. P., Pinto Jr., O., Pinto, I. R. C. A.: A detection efficiency model for the Brazilian Lightning Detection Network (RINDAT), Proceedings of the 19th International Lightning Detection Conference, Vaisala, Tucson, 2006.

Neubert, T., Allin, T. H., Stenbaek-Nielsen, H., and Blanc, E.: Sprites over Europe, J. Geophys. Res. Lett., 28, 3585-3588, 2001.

Pasko, V. P., Inan, U. S., and Bell, T. F.: Sprites as evidence of vertical gravity wave structures above mesoscale thunderstorms, Geophys. Res. Lett., 24, 1735-1738, 1997a.

Pasko, V. P., Inan, U. S., and Bell, T. F.: Sprites produced by Quasielectrostatic heating and ionization in the lower ionosphere, J. Geophys. Res., 102, 4529-4561, 1997b.

Piani, C., Durran, D., Alexander, M. J., and Holton, J. R.: A numerical study of three-dimensional gravity waves triggered by deep tropical convection, J. Atmos. Sci., 57, 3689-3702, 2000.

Pinto Jr., O., Pinto, I. R. C. A., and Naccarato, K. P.: Maximum cloud-to-ground lightning flash densities observed by lightning location systems in the tropical region: A review, Atmos. Res., 84, 189-200, 2007.

São Sabbas, F. T. and Sentman, D. D.: Dynamical relationship of infrared cloud top temperatures with occurrence rates of cloudto-ground lightning and sprites, Geophys. Res. Lett., 30(5), 401-40-4, 2003b.

São Sabbas, F. T., Sentman, D. D., Wescott, E. M., Pinto Jr., O., Mendes Jr., O., and Taylor, M. J.: Statistical analysis of spacetime relationships between sprites and lightning, J. Atmos. SolarTerr. Phys., 65(5), 523-533, 2003a.

São Sabbas, F. T.: Role of conductivity spatial structure in determining the locations of sprite initiation, PhD Dissertation, Univerisity of Alaska Fairbanks, Fairbanks, 2003.

São Sabbas, F. T., Rampinelli, V. T., Pautet, P. D., Taylor, M. J., Bailey, M., Solorzano, N. N., Thomas, J. N., Cummer, S., Holzworth, R. H., Pinto, O., and Schuch, N. J.: IR Temperature Char- acteristics of a Prolific TLE Producing Storm in South America Observed During a Sprite Campaign in Brazil, EOS Trans. AGU, 88(52), Fall Meet. Suppl., Abstract AE42A-04, 2007.

Schmetz, J., Tjemkes, S. A., Gube, M., and Van de Berg, L.: Monitoring deep convection and convective overshooting, Adv. Space Res., 19(3), 433-441, 1997.

Sentman, D. D., Wescott, E. M., Osborne, D. L., Heavner, M. J., and Hampton, D. L.: The Peru95 Sprites Campaign: Overview, EOS Trans. AGU, 76, F238 (Abstract), 1995.

Sentman, D. D., Wescott, E. M., Picard, R. H., Winick, J. R., Stenbaek-Nielsen, H. C., Dewan, E. M., Moudry, D. R., São Sabbas, F. T., Heavner, M. J., and Morrill, J.: Simultaneous observations of mesospheric gravity waves and sprites generated by a midwestern thunderstorm, J. Atmos. Solar-Terr. Phys., 65, 537550, 2003.

Taylor, M. J. and Hapgood, M. A.: Identification of a thunderstorm as a source of short period gravity waves in the upper atmospheric nightglow emissions, Planet. Space Sci., 36, 975-985, 1988.

Taylor, M. J., Gardner, L. C., Siefring, C.: Image measurements during the 1999 Leonids-MAC Airborne Campaign: Highresolution meteor ablation signatures and longitudinal gravity wave study, Proc. 2nd Leonids-MAC workshop (Abstract), Tel Aviv, April 2000.

Taylor, M. J., Pautet, P.-D., Medeiros, A. F., Buriti, R., Fechine, J., Fritts, D. C., Vadas, S. L., Takahashi, H., and São Sabbas, F. T.: Characteristics of mesospheric gravity waves near the magnetic equator, Brazil, during the SpreadFEx campaign, Ann. Geophys., 27, 461-472, 2009,

http://www.ann-geophys.net/27/461/2009/.

Takahashi, H., Taylor, M. J., Pautet, P.-D., Medeiros, A. F., Gobbi, D., Wrasse, C. M., Fechine, J., Abdu, M. A., Batista, I. S., Paula, E., Sobral, J. H. A., Arruda, D., Vadas, S., Sabbas, F. S., and Fritts, D.: Simultaneous observation of ionospheric plasma bubbles and mesospheric gravity waves during the SpreadFEx Campaign, Ann. Geophys., in press, 2009.

Thomas, J. N., Taylor, M. J., Pautet, P. D., Bailey, M., Solorzano, N. N., Holzworth, R. H., McCarthy, M., Kokorowski, M., São Sabbas, F. T., Pinto, O., Cummer, S., Jaugey, N., Li, J., Schuch, N. J.: A Very Active Sprite-Producing Storm Observed over Argentina, EOS Trans. Am. Geophys. Union, 88(10), doi:10.1029/2007EO100001, 2007.

Vadas, S. L. and Fritts, D. C.: The influence of increasing temperature and solar variability on gravity wave structure and dissipation in the thermosphere, J. Geophys. Res., TIMED special issue, 111, A10812, doi:10.1029/2005JA011510, 2006.

Vadas, S. L. and Fritts, D. C.: Thermospheric responses to gravity waves arising from mesoscale convective complexes, J. Atmos. Solar Terr. Phys., 66, 781-804, 2004.

Vadas, S. L., Taylor, M. J., Pautet, P.-D., Stamus, P. A., Fritts, D. C., Liu, H.-L., São Sabbas, F. T., Rampinelli, V. T., Batista, P., and Takahashi, H.: Convection: the likely source of the medium-scale gravity waves observed in the $\mathrm{OH}$ airglow layer near Brasilia, Brazil, during the SpreadFEx campaign, Ann. Geophys., 27, 231-259, 2009, http://www.ann-geophys.net/27/231/2009/.

Vargas, F., Gobbi, D., and Takahashi, T.: Gravity wave amplitudes and momentum fluxes inferred from $\mathrm{OH}$ airglow intensities and meteor radar winds during SpreadFEx, Ann. Geophys., in review, 
2009.

Wescott, E. M., Sentman, D. D., Heavner, M. J., Hampton, D. L., Lyons, W. A., and Nelson, T.: Observations of "Columniform" sprites, J. Atmos. Solar-Terr. Phys., 60, 733-740, 1998.

Wescott, E. M., Stenbaek-Nielsen, H. C., Sentman, D. D., Heavner, M. J., Moudry, D. R., and São Sabbas, F. T.: Triangulation of sprites, associated halos and their possible relation to causative lightning and micro-meteors, J. Geophys. Res., 106(A6), 1046710477, 2001.
Wrasse, C. M., Takahashi, H., Fechine, J., Medeiros, A. F., and Bageston, J. V.: Ray tracing of GWs observed in $\mathrm{OH}$ airglow during SpreadFEx, Ann. Geophys., in review, 2009. 